$\begin{array}{ll}\text { Research Square } & \text { Preprints are preliminary reports that have not undergone peer review. } \\ \text { They should not be considered conclusive, used to inform clinical practice, } \\ \text { or referenced by the media as validated information. }\end{array}$

\title{
Recurrence of ameloblastoma in an autogenous bone graft 10 years after initial operation: A case report and literature review
}

si wu

First People's Hospital of Yichang

Hui Yan

First People's Hospital of Yichang

Lin Han

First People's Hospital of Yichang

Huaizhou Yu ( $\nabla$ yyhz2003@163.com)

First People's Hospital of Yichang https://orcid.org/0000-0002-3547-5570

\section{Case report}

Keywords: Ameloblastoma; Recurrence; Bone graft

Posted Date: June 22nd, 2020

DOI: https://doi.org/10.21203/rs.3.rs-36116/v1

License: (c) (1) This work is licensed under a Creative Commons Attribution 4.0 International License. Read Full License 


\section{Abstract}

Background: Ameloblastoma is an asymptomatic locally invasive slow-growing odontogenic epithelial tumor. it is rare that the tumor developing in the autogenous bone graft.

Case presentation: This report describes a case of ameloblastoma recurrence in an autogenous iliac bone graft 10 years after initial operation in a 37-year-old female who had a history of partial mandibulectomy + left iliac bone graft for ameloblastoma. In 2016 year, the patient was therefore admitted to our hospital for a second surgery, In 2017, 2018, 2019 after the second surgery, radiograph examination showed no recurrence after the surgery.

Conclusions: Awareness of the concept of tumor-free operation, extensively resect the affected bone and soft tissue may help in ameloblastoma recurrence, Pathological diagnosis and long-term regular follow-up visits should help improve long-term outcome

\section{Background}

Ameloblastoma is an asymptomatic locally invasive slow-growing odontogenic epithelial tumor. the classification of ameloblastomas has been simplified and narrowed to ameloblastoma, unicystic ameloblastoma and extraosseous/peripheral types[1]. So many reports on local recurrence of ameloblastoma, however, Recurrence of ameloblastoma in autogenous iliac bone grafts has rarely been reported in the literature. Here, we discuss a case of recurrent ameloblastoma in an autogenous iliac bone graft 10 years after initial operation (partial mandibulectomy + left iliac bone grafts) and review the literature on recurrent ameloblastomas in the bone graft.

\section{Case Presentation}

In 2016, a 37-year-old female reported discomfort during mastication and dull pain in the left mandibular bone over the course of a month. At hospital examination, according to our records, we found she had been admitted to our surgical center in 2006 and safely received partial mandibulectomy surgery through an intraoral approach, whereby the mandible defect was reconstructed with the left autogenous iliac bone. The mandible was diagnosed with ameloblastoma upon pathological examination, but the histological subtype of the ameloblastoma was not reported.

In 2016, however, the patient returned to the hospital. Clinical examination revealed facial swelling and tenderness of the left mandible and increased mandibular volume in the left region of the mandible with no remarkable inflammation. Panoramic radiographs showed a large multilocular radiolucency occupying in the left mandibular grafted bone and metal wires (Fig. 1). Three-dimensional computed tomography (CT) of the maxillofacial region showed expansion of the grafted bone with multilocular radiolucency of $33 \mathrm{~mm} \times 24 \mathrm{~mm}$, but no extension of the tumor mass to adjacent soft tissue (Fig. 2).

The patient was therefore admitted to the hospital for a second surgery. The expanded grafted bone was resected completely, the excision of the lesion with $1 \mathrm{~cm}$ uninvolved mandible margin was performed,and the mandible was reconstructed using her right iliac bone, which was fixed and installed using titanium plates. Histopathological features revealed follicular ameloblastoma with acanthomatous changes with tumor- free margins (Fig. 3). A photomicrograph of the original tumor showed formation of keratinized beads (Fig. 4) and that the nuclei were arranged in a fence shape and were far from the basement membrane, that is, polarity was inverted.

In 2017, 2018, 2019 after the second surgery, radiograph examination (Fig. 5-7) showed no recurrence after surgery. 


\section{Discussion}

Various prognoses of postoperative ameloblastoma have been reported based on type of surgery, including enucleation, curettage, and radical resection [2].

Almeida et al. [3] found that the recurrence rate after conservative treatment was 3.15 times higher than that after radical resection. According to Carlson et al. [4], conservative measures such as enucleation, enucleation and curettage, surgical excision and peripheral ostectomy, and enucleation with liquid nitrogen cryotherapy, it means an inadequate removal of tumor, but radical resection means the soft and hard tissue margins in the resection of tumor are determined to be histopathologically negative.

Regarding some patients are younger, there is a tendency towards more conservative measures for the aesthetic, functional, and psychological effects[3]. Radical resection is indicated for the solid or multicystic ameloblastoma[4, 5], these principles of radical resection will increase the likelihood of tumor-free margins in the final histopathologic sections: assessment of anatomic barriers; resection with $1 \mathrm{~cm}$ to $1.5 \mathrm{~cm}$ linear bone margins; the use of specimen radiographs and the use of frozen section.

Additionally, the initial surgical approach was correlated with the recurrence risk[6]. In our report, intraoperative frozen pathological examination was not performed during the first operation in 2006. So that the patient with simultaneous radical resection and bone reconstruction, should be performed the radical surgery to ensure that the stump of the bone is normal, and there was no tumor cell surrounding the soft tissue.Regardless of treatment method, regular follow-up is necessary after surgery. Almeida et al. [3] suggested that panoramic films should be reviewed every six months for the first five years after surgery, every year for 5-10 years after surgery, and every 2-3 years after 10 years. In our report, the follow-up of the patient was irregular and unsustainable because of the relatively low levels of dental care in China. Now the electronic medical record information in our city is gradually developing, Patients are not regularly followed-up can be reached and remaindered .

Patients with concurrent radical resection and bone reconstruction should receive regular follow-up for at least 10 years, it was the significant factor that could be helpful in early diagnosis and therapy. If recurrent ameloblastoma is suspected during re-examination, CT may be required.

According to Su et al. [7], patients with pathological diagnosis of general ameloblastoma should be provided with regular reviews for more than 10 years. But even with long-term follow-up, recurrence of ameloblastoma in situ may still occur. Therefore, pathological examinations are essential for patients under long-term clinical review, which should help improve long-term prognosis. Many factors, such as clinical type, surgical technique, number of cases, and length of follow-up, impact recurrence rates [8]. In the 2005 WHO, Ameloblastomas were classified as solid/multicystic, extraosseous/peripheral, desmoplastic and unicystic types[9]. but in 2017, the classification of ameloblastomas has been simplified and narrowed. "solid/multicystic" was dropped because it has no biologic significance, but its clinical and radiographic features sometimes was unique[1]. Records in literatures [5-8, 10-23] (table 1)among 25 patients which are about 10 patients graft bone CT showed multicystic[6-8, 12, 15, 18, 19, 21,22]. Only 12 patients showed the pathological findings, 6 showed acanthomatous ameloblastoma[5-8, 12, 17, 18, 21, 22]. A multilocular radiographic image and follicular were presented a significantly higher number of recurrences, and it is in agreement with data reported in the international literature[24].

At present, the mechanism of recurrent ameloblastoma in grafted bone is still unclear [25]. Three possible explanations of the recurrence of ameloblastoma in grafted bone have been reported: i.e., 1) residual tumor cells in stumps; 2) residual tumor cells in soft tissues; and 3) tumor cells implanted in the bone during operation $[14,18]$. According to our 
case, the patient's three-dimensional CT showed that the recurrent lesions in the mandible bone were mainly invasive, i.e., the lesions invaded the grafted autogenous bone, resulting in a polycystic change. According to the clinical manifestations and auxiliary examination of the patient, A $1 \mathrm{~cm}$ to $1.5 \mathrm{~cm}$ bony linear margin and an intraoperative specimen radiograph could provide a margin-free specimen[4]. This standard of the surgery is an opportunity to assess the adequacy of the resection. Encounter the anatomic barrier of cortical bone, this should be assessed and determined preoperatively and precisely dissected intraoperatively, it depends on the experience of the surgeon. In our case, en-bloc resection and affected surrounding soft tissue maybe a cause of the second recurrence. This is consistent with the literature $[6,8,12,14,15,18,19]$. We still need to follow up patients continuously, and we look forward to more studies.

\section{Conclusions}

Here, we reported on a case of recurrent ameloblastoma after 10 years. We should pay attention to the concept of tumor-free operation, extensively resect the affected bone and soft tissue, carefully treat the stump, and then transplant the autogenous iliac bone to restore the defective mandibular shape and function. At the same time, Pathological diagnosis and long-term and regular follow-up visits should help improve long-term outcome. 
Table 2

Distribution of patients with ameloblastomas invading bone grafts reported in the literature.

\begin{tabular}{|c|c|c|c|c|c|c|}
\hline study & $\begin{array}{l}\text { Gender } \\
\text { age }\end{array}$ & $\begin{array}{l}\text { Tumor } \\
\text { location }\end{array}$ & $\begin{array}{l}\text { Interval of } \\
\text { Graft } \\
\text { Recurrence } \\
\text { (Years) }\end{array}$ & $\begin{array}{l}\text { Panoramic } \\
\text { radiographs }\end{array}$ & Final Treatment & $\begin{array}{l}\text { Pathological of } \\
\text { graft bone }\end{array}$ \\
\hline Graft et al.(1970) & $F / 15$ & $\begin{array}{l}\text { Mandible } \\
\text { (L.P) }\end{array}$ & $\begin{array}{l}\text { lliac } \\
\text { bone/13 }\end{array}$ & - & $\begin{array}{l}\text { Explantation and } \\
\text { new graft }\end{array}$ & - \\
\hline $\begin{array}{l}\text { Carvalho et al. } \\
\text { (1976) }\end{array}$ & $F / 52$ & $\begin{array}{l}\text { Mandible } \\
(\mathrm{L})\end{array}$ & $\begin{array}{l}\text { lliac } \\
\text { bone/13 }\end{array}$ & - & Mandibulectomy & - \\
\hline $\begin{array}{l}\text { Dolan et al. } \\
\text { (1981) }\end{array}$ & $M / 63$ & $\begin{array}{l}\text { Mandibular } \\
\text { (A) }\end{array}$ & $\begin{array}{l}\text { Rib } \\
\text { bone/13 }\end{array}$ & $\begin{array}{l}\text { multilocular } \\
\text { radiolucent }\end{array}$ & $\begin{array}{l}\text { Mandibulectomy } \\
+ \text { Iliac graft }\end{array}$ & $\begin{array}{l}\text { acanthomatous } \\
\text { ameloblastoma }\end{array}$ \\
\hline $\begin{array}{l}\text { Marinelli et al. } \\
\text { (1982) }\end{array}$ & M/-- & $\begin{array}{l}\text { Mandible } \\
(\mathrm{L} . \mathrm{P})\end{array}$ & $\begin{array}{l}\text { lliac } \\
\text { bone/13 }\end{array}$ & - & Curettage & - \\
\hline Stea(1985) & $F / 39$ & $\begin{array}{l}\text { Mandible } \\
(L . P)\end{array}$ & Iliac bone/7 & - & curettage & - \\
\hline \multirow[t]{4}{*}{ Zacharides(1988) } & $M / 25$ & $\begin{array}{l}\text { Mandibular } \\
\text { (A) }\end{array}$ & $\begin{array}{l}\text { Rib } \\
\text { bone/36 }\end{array}$ & - & Missed follow-up & - \\
\hline & $\mathrm{M} / 48$ & $\begin{array}{l}\text { Mandible } \\
(\mathrm{L})\end{array}$ & $\begin{array}{l}\text { autogenous } \\
\text { bone(bone } \\
\text { chips)/2 }\end{array}$ & - & Missed follow-up & - \\
\hline & $M / 62$ & $\begin{array}{l}\text { Mandibular } \\
\text { (L. Ra) }\end{array}$ & Iliac bone/4 & - & Curettage & - \\
\hline & $F / 22$ & $\begin{array}{l}\text { Mandibular } \\
\text { (R. P\&Ra) }\end{array}$ & $\begin{array}{l}\text { autogenous } \\
\text { bone/7 }\end{array}$ & $\begin{array}{l}\text { multilocular } \\
\text { radiolucent }\end{array}$ & $\begin{array}{l}\text { Resection,Missed } \\
\text { follow-up }\end{array}$ & - \\
\hline Vasan(1995) & $\mathrm{M} / 42$ & $\begin{array}{l}\text { Mandibular } \\
\text { (R.P) }\end{array}$ & $\begin{array}{l}\text { lliac } \\
\text { bone/28 }\end{array}$ & - & Enucleation & - \\
\hline $\begin{array}{l}\text { Bianchi et al. } \\
\text { (1998) }\end{array}$ & $\mathrm{F} / 19$ & $\begin{array}{l}\text { Mandibular } \\
\text { (R.P) }\end{array}$ & $\begin{array}{l}\text { iliac } \\
\text { bone/27 }\end{array}$ & - & Enucleation & $\begin{array}{l}\text { follicular cystic } \\
\text { ameloblastoma }\end{array}$ \\
\hline $\begin{array}{l}\text { Martins and } \\
\text { Favaro(2004) }\end{array}$ & $\mathrm{F} / 17$ & $\begin{array}{l}\text { Mandibular } \\
\text { (R.P) }\end{array}$ & $\begin{array}{l}\text { iliac } \\
\text { bone/16 }\end{array}$ & $\begin{array}{l}\text { multilocular } \\
\text { radiolucent }\end{array}$ & $\begin{array}{l}\text { Segmental } \\
\text { resection }+ \\
\text { Kirschner wire } \\
\text { with autogenous } \\
\text { cancellous bone } \\
\text { graft }\end{array}$ & 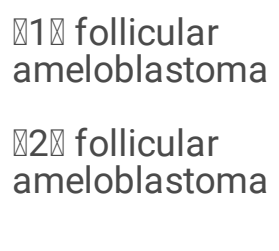 \\
\hline \multirow{3}{*}{$\begin{array}{l}\text { Su et al.(2006) } \\
\text { (Article in Chinese }\end{array}$} & $F / 55$ & $\begin{array}{l}\text { Mandibular } \\
(\text { L. P) }\end{array}$ & $\begin{array}{l}\text { Rib } \\
\text { bone/16 }\end{array}$ & $\begin{array}{l}\text { multilocular } \\
\text { radiolucent }\end{array}$ & $\begin{array}{l}\text { Partial } \\
\text { mandibulectomy } \\
\text { + free fibular flap }\end{array}$ & $\begin{array}{l}\text { follicular } \\
\text { ameloblastoma }\end{array}$ \\
\hline & M/38 & $\begin{array}{l}\text { Mandibular } \\
(\text { L. P) }\end{array}$ & Iliac bone/3 & - & $\begin{array}{l}\text { Partial } \\
\text { mandibulectomy } \\
+ \text { rib graft }\end{array}$ & $\begin{array}{l}\text { follicular } \\
\text { ameloblastoma }\end{array}$ \\
\hline & $F / 29$ & $\begin{array}{l}\text { Mandibular } \\
\text { (R.P) }\end{array}$ & $\begin{array}{l}\text { autogenous } \\
\text { bone/4 }\end{array}$ & - & $\begin{array}{l}\text { Partial } \\
\text { mandibulectomy } \\
\text { + free fibular flap }\end{array}$ & $\begin{array}{l}\text { plexiform } \\
\text { ameloblastoma }\end{array}$ \\
\hline
\end{tabular}




\begin{tabular}{|c|c|c|c|c|c|c|}
\hline study & $\begin{array}{l}\text { Gender } \\
\text { age }\end{array}$ & $\begin{array}{l}\text { Tumor } \\
\text { location }\end{array}$ & $\begin{array}{l}\text { Interval of } \\
\text { Graft } \\
\text { Recurrence } \\
\text { (Years) }\end{array}$ & $\begin{array}{l}\text { Panoramic } \\
\text { radiographs }\end{array}$ & Final Treatment & $\begin{array}{l}\text { Pathological of } \\
\text { graft bone }\end{array}$ \\
\hline \multirow[t]{2}{*}{ Choi et al.(2006) } & $M / 52$ & $\begin{array}{l}\text { Mandibular } \\
\text { (R.P) }\end{array}$ & $\begin{array}{l}\text { iliac } \\
\text { bone/20 }\end{array}$ & $\begin{array}{l}\text { multilocular } \\
\text { radiolucent }\end{array}$ & Radical & $\begin{array}{l}\text { (1)an } \\
\text { acanthomatous } \\
\text { ameloblastoma } \\
\text { with a follicular } \\
\text { pattern }\end{array}$ \\
\hline & & & & & & $\begin{array}{l}\text { (2)a follicular } \\
\text { and plexiform } \\
\text { microscopic } \\
\text { pattern }\end{array}$ \\
\hline \multirow[t]{2}{*}{$\begin{array}{l}\text { Eckardt, A. M et } \\
\text { al.(2009) }\end{array}$} & 26 & $\begin{array}{l}\text { Mandibular } \\
\text { (R.P) }\end{array}$ & $\begin{array}{l}\text { iliac } \\
\text { bone/35.5 }\end{array}$ & - & $\begin{array}{l}\text { Segmental } \\
\text { resection + radial } \\
\text { forearm flap }\end{array}$ & $\begin{array}{l}\text { acanthomatous } \\
\text { ameloblastoma }\end{array}$ \\
\hline & 49 & $\begin{array}{l}\text { Mandibular } \\
(\mathrm{R})\end{array}$ & $\begin{array}{l}\text { iliac } \\
\text { bone/11 }\end{array}$ & - & $\begin{array}{l}\text { Further } \\
\text { continuity } \\
\text { resection + } \\
\text { bicortical iliac } \\
\text { crest bone }\end{array}$ & $\begin{array}{l}\text { follicular } \\
\text { ameloblastoma }\end{array}$ \\
\hline $\begin{array}{l}\text { Essaadi, M et al. } \\
\text { (2010) }\end{array}$ & $F / 59$ & $\begin{array}{l}\text { Mandibular } \\
\text { (L.P) }\end{array}$ & rib bone/33 & - & $\begin{array}{l}\text { The excision of } \\
\text { the lesion }\end{array}$ & - \\
\hline \multirow{2}{*}{$\begin{array}{l}\text { Jian et al.(2015) } \\
\text { (Article in Chinese } \\
\end{array}$} & M/33 & $\begin{array}{l}\text { Mandibular } \\
\text { (R.P) }\end{array}$ & $\begin{array}{l}\text { iliac } \\
\text { bone/16 }\end{array}$ & $\begin{array}{l}\text { multilocular } \\
\text { radiolucen }\end{array}$ & $\begin{array}{l}\text { Partial } \\
\text { mandibulectomy } \\
\text { + free fibular flap }\end{array}$ & - \\
\hline & M/29 & $\begin{array}{l}\text { Mandibular } \\
\text { (R.P) }\end{array}$ & $\begin{array}{l}\text { Rib } \\
\text { bone/14 }\end{array}$ & $\begin{array}{l}\text { multilocular } \\
\text { radiolucent }\end{array}$ & -- & - \\
\hline Basat et al.(2015) & $F / 26$ & $\begin{array}{l}\text { Mandibular } \\
\text { (L.P) }\end{array}$ & $\begin{array}{l}\text { fibular } \\
\text { flap/14 }\end{array}$ & $\begin{array}{l}\text { unilocular } \\
\text { radiolucency }\end{array}$ & $\begin{array}{l}\text { Explantation and } \\
\text { radical } \\
\text { mandibulectomy } \\
\text { reconstruction } \\
\text { plate }\end{array}$ & - \\
\hline $\begin{array}{l}\text { Aramanadka et } \\
\text { al.(2018) }\end{array}$ & $\mathrm{M} / 46$ & $\begin{array}{l}\text { Mandibular } \\
\text { (R. P) }\end{array}$ & $\begin{array}{l}\text { Rib } \\
\text { bone/15 }\end{array}$ & $\begin{array}{l}\text { multilocular } \\
\text { radiolucent }\end{array}$ & $\begin{array}{l}\text { The excision of } \\
\text { the lesion }\end{array}$ & $\begin{array}{l}\text { follicular } \\
\text { ameloblastoma } \\
\text { with } \\
\text { acanthomatous } \\
\text { changes }\end{array}$ \\
\hline Hu Y et al.(2019) & $F / 31$ & $\begin{array}{l}\text { Mandibular } \\
(\text { L. P) }\end{array}$ & iliac bone/ 6 & $\begin{array}{l}\text { multilocular } \\
\text { radiolucent }\end{array}$ & $\begin{array}{l}\text { Explantation and } \\
\text { radical } \\
\text { mandibulectomy } \\
\text { + DCIA flap }\end{array}$ & $\begin{array}{l}\text { follicular } \\
\text { ameloblastoma }\end{array}$ \\
\hline $\begin{array}{l}\text { Hamdy, O et al. } \\
(2020)\end{array}$ & $\mathrm{F} / 75$ & $\begin{array}{l}\text { Mandibular } \\
(\text { R. P) }\end{array}$ & rib bone/17 & $\begin{array}{l}\text { multilocular } \\
\text { cystic }\end{array}$ & $\begin{array}{l}\text { The excision of } \\
\text { the lesion }\end{array}$ & $\begin{array}{l}\text { follicular } \\
\text { ameloblastoma } \\
\text { with } \\
\text { acanthomatous } \\
\text { changes }\end{array}$ \\
\hline
\end{tabular}




\section{Availability of data and materials}

All data generated or analyzed are included in this published article.

\section{Ethics approval and consent to participate}

Not applicable.

\section{Consent for publication}

We obtained the patient's consent for publication.

\section{Competing interests}

The authors have no conflicts of interest to declare.

\section{Author Contributions}

HZ Y conceived this study and made critical revisions to the manuscript. SW designed this study, drafted the manuscript, and reviewed all references. LH Performed the histological examination and made the histological diagnosis of the tumor. YH collected data and references.

\section{Acknowledgements}

None applicable.

\section{References}

1. Wright JM, Vered M. Update from the 4th Edition of the World Health Organization Classification of Head and Neck Tumours: Odontogenic and Maxillofacial Bone Tumors. Head Neck Pathol. 2017;11(1):68-77.

2. Bataineh $A B$. Effect of preservation of the inferior and posterior borders on recurrence of ameloblastomas of the mandible. Oral Surg Oral Med Oral Pathol Oral Radiol Endod. 2000;90(2):155-63.

3. Almeida Rde A, et al. Recurrence rate following treatment for primary multicystic ameloblastoma: systematic review and meta-analysis. Int J Oral Maxillofac Surg. 2016;45(3):359-67.

4. Carlson ER, Marx RE. The ameloblastoma: primary, curative surgical management. J Oral Maxillofac Surg. 2006;64(3):484-94.

5. Eckardt AM, et al. Recurrent ameloblastoma following osseous reconstruction-a review of twenty years. J Craniomaxillofac Surg. 2009;37(1):36-41.

6. Hu Y, et al. Reconstruction of Deep Circumflex Iliac Artery Free Flap for Multiple Recurrent Ameloblastoma in Mandible. J Craniofac Surg. 2019;30(2):557-62.

7. Su T, et al. [Ameloblastoma recurrence in the grafted iliac bone: report of three cases]. Shanghai Kou Qiang Yi Xue. 2006;15(1):109-11.

8. Choi YS, et al. A case of recurrent ameloblastoma developing in an autogenous iliac bone graft 20 years after the initial treatment. Dentomaxillofac Radiol. 2006;35(1):43-6. 
9. Teng XD. [World Health Organization classification of tumours, pathology and genetics of tumours of the lung]. Zhonghua Bing Li Xue Za Zhi. 2005;34(8):544-6.

10. Grafft ML, et al. Ameloblastoma recurring in previously placed iliac crest autograft: report of case. J Oral Surg. 1970;28(4):285-91.

11. Carvalho FS, Cespedes VG. CE., Ameloblastoma (recurrence after 21 months). Rev Assoc Med Minas Gerais. 1976;27:28-30.

12. Dolan EA, Angelillo JC, Georgiade NG. Recurrent ameloblastoma in autogenous rib graft. Report of a case. Oral Surg Oral Med Oral Pathol. 1981;51(4):357-60.

13. Marinelli M, Vallogini BD. P, et al., Ameloblastoma recidnivo in trapianto autogeno di cresta iliaca. In: Giardino G, editor Maxillofacial Surgery., 1982. 19: p. 94-6.

14. Stea G. Recurrence of an ameloblastoma in an autogenous iliac bone graft. J Oral Maxillofac Surg. 1985;43(5):374-7.

15. Zachariades N. Recurrences of ameloblastoma in bone grafts. Report of 4 cases. Int J Oral Maxillofac Surg. 1988;17(5):316-8.

16. Vasan NT. Recurrent ameloblastoma in an autogenous bone graft after 28 years: a case report. N Z Dent J. 1995;91(403):12-3.

17. Bianchi SD, et al. Ameloblastoma of the mandible involving an autogenous bone graft. J Oral Maxillofac Surg. 1998;56(10):1187-91.

18. Martins WD, Favaro DM. Recurrence of an ameloblastoma in an autogenous iliac bone graft. Oral Surg Oral Med Oral Pathol Oral Radiol Endod. 2004;98(6):657-9.

19. Xin-chun Jian1

Xin-chun Jian1. Liu De-yu1, Zhu R 1, Chao Zhou2, Xiao-shan Wu2, Pu Xu1, Ning Li2, Li-meng Wu2, Qun-hao Zhuo2, Recurrences of Ameloblastoma in Bone Grafts: Report of Two Cases and Literature Review. China Journal of Oral and Maxillofacial Surgery, 2015. 13(01): p. 94-96.

20. Basat SO, et al. Recurrent Ameloblastoma in the Free Fibula Flap: Review of Literature and an Unusual Case Report. J Maxillofac Oral Surg. 2015;14(3):821-5.

21. Aramanadka C, Kamath AT, Kudva A, Recurrent Ameloblastoma: A Surgical Challenge. Case Rep Dent, 2018. 2018: p. 8271205.

22. Hamdy 0 , et al. Recurrent mandibular ameloblastoma in soft tissue and rib graft 17 years after initial presentation. J Egypt Natl Canc Inst. 2020;32(1):1.

23. Essaadi $M$, et al. [Recurrent ameloblastoma on a rib graft after 33 years (a case report and review of the literature)]. Rev Laryngol Otol Rhinol (Bord). 2010;131(4-5):303-6.

24. Fregnani ER, et al. Clinicopathological study and treatment outcomes of 121 cases of ameloblastomas. Int J Oral Maxillofac Surg. 2010;39(2):145-9.

25. Montoro JR, et al. Mandibular ameloblastoma treated by bone resection and immediate reconstruction. Braz J Otorhinolaryngol. 2008;74(1):155-7.

\section{Figures}




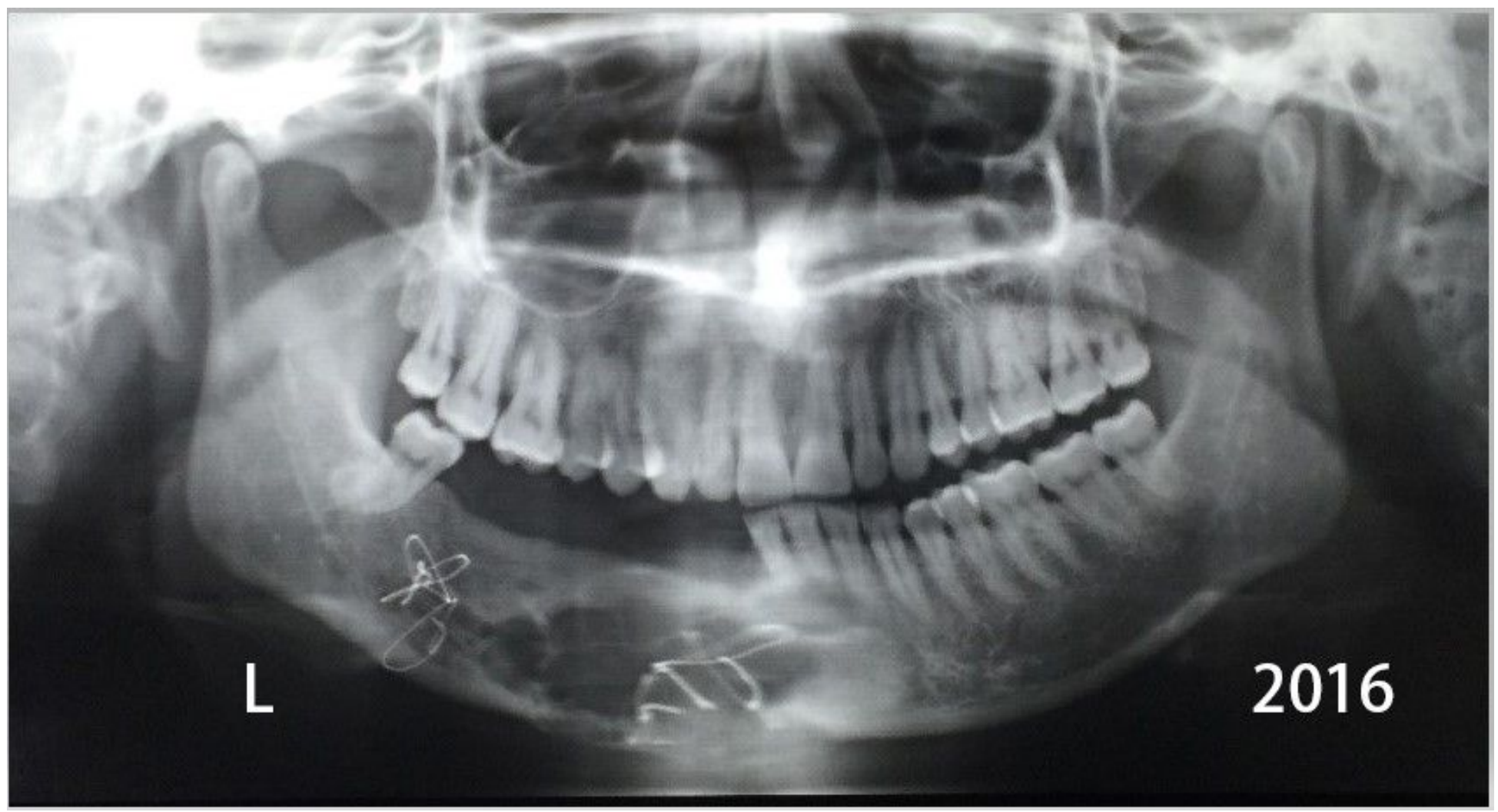

\section{Figure 1}

Panoramic radiographs showed a large multilocular radiolucency occupying the left mandibular graft bone and metal wires. 


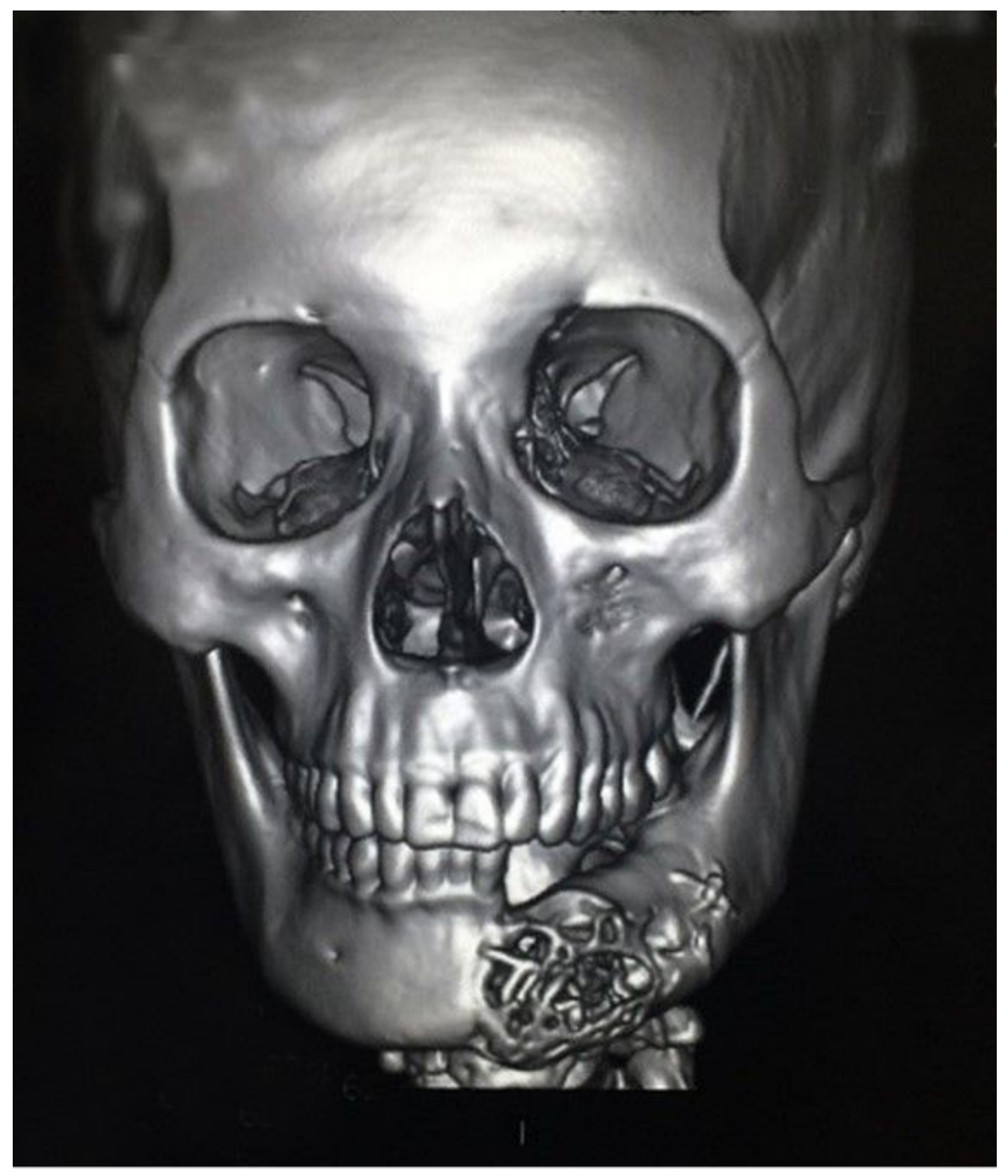

\section{Figure 2}

Three-dimensional computed tomography (CT) examination of the maxillofacial region showed that expansion of the grafted bone with multilocular radiolucency was about $33 \mathrm{~mm} \times 24 \mathrm{~mm}$ and no extension of the tumor mass to adjacent soft tissue. 


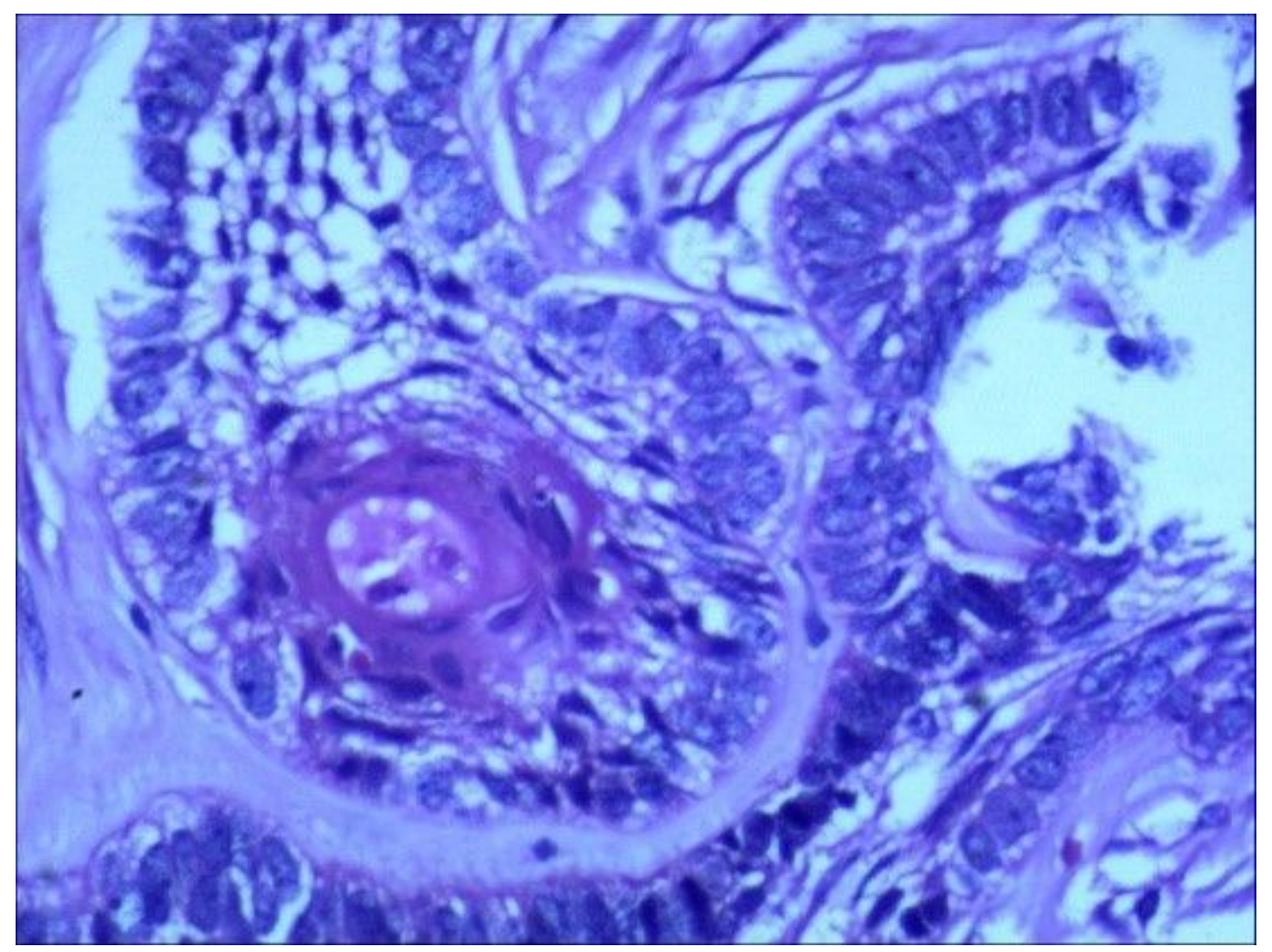

\section{Figure 3}

HE staining ( $\times 400)$ : follicular pattern.

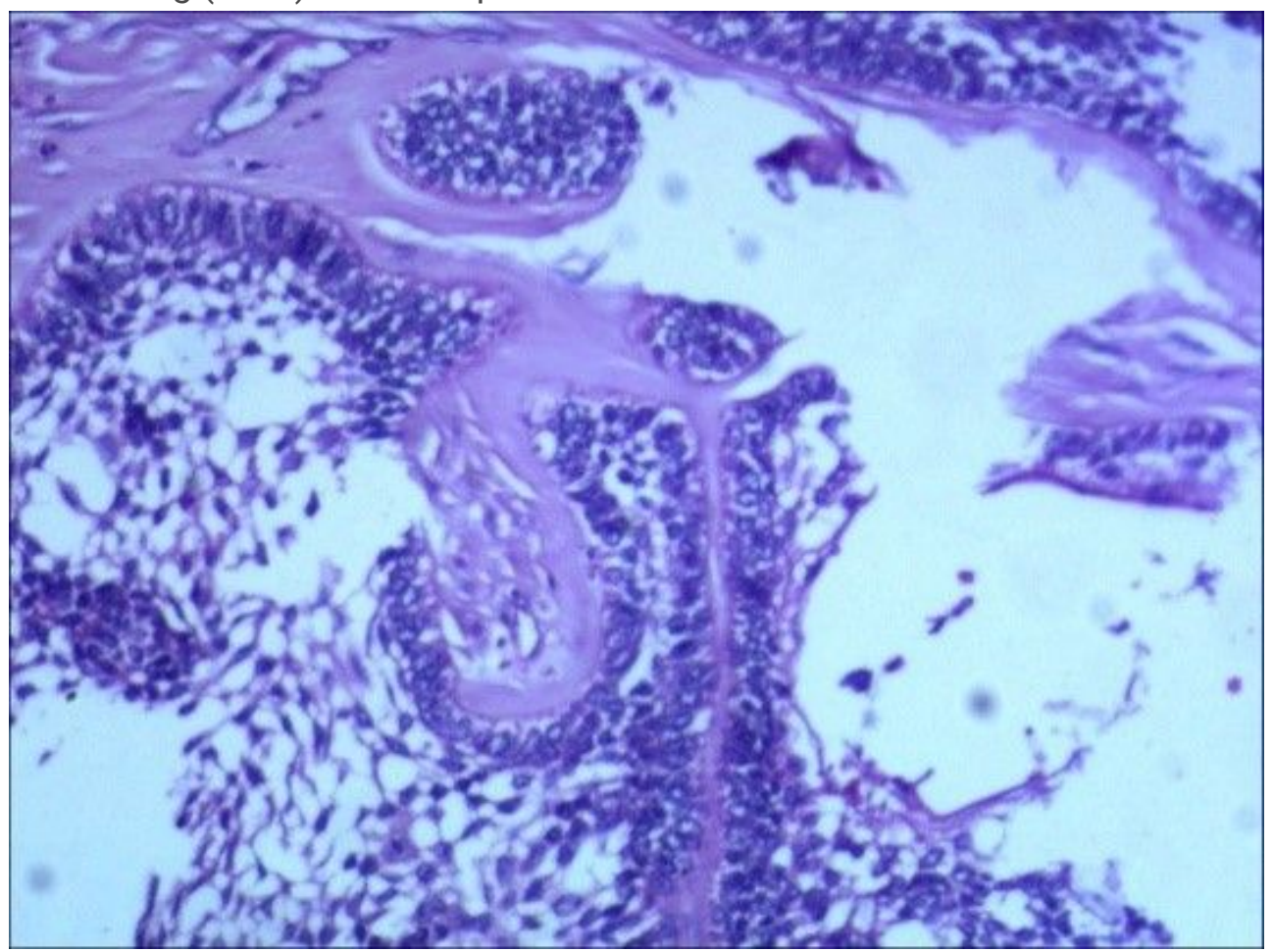

Figure 4

HE staining $(\times 400)$ : acanthomatous pattern. 


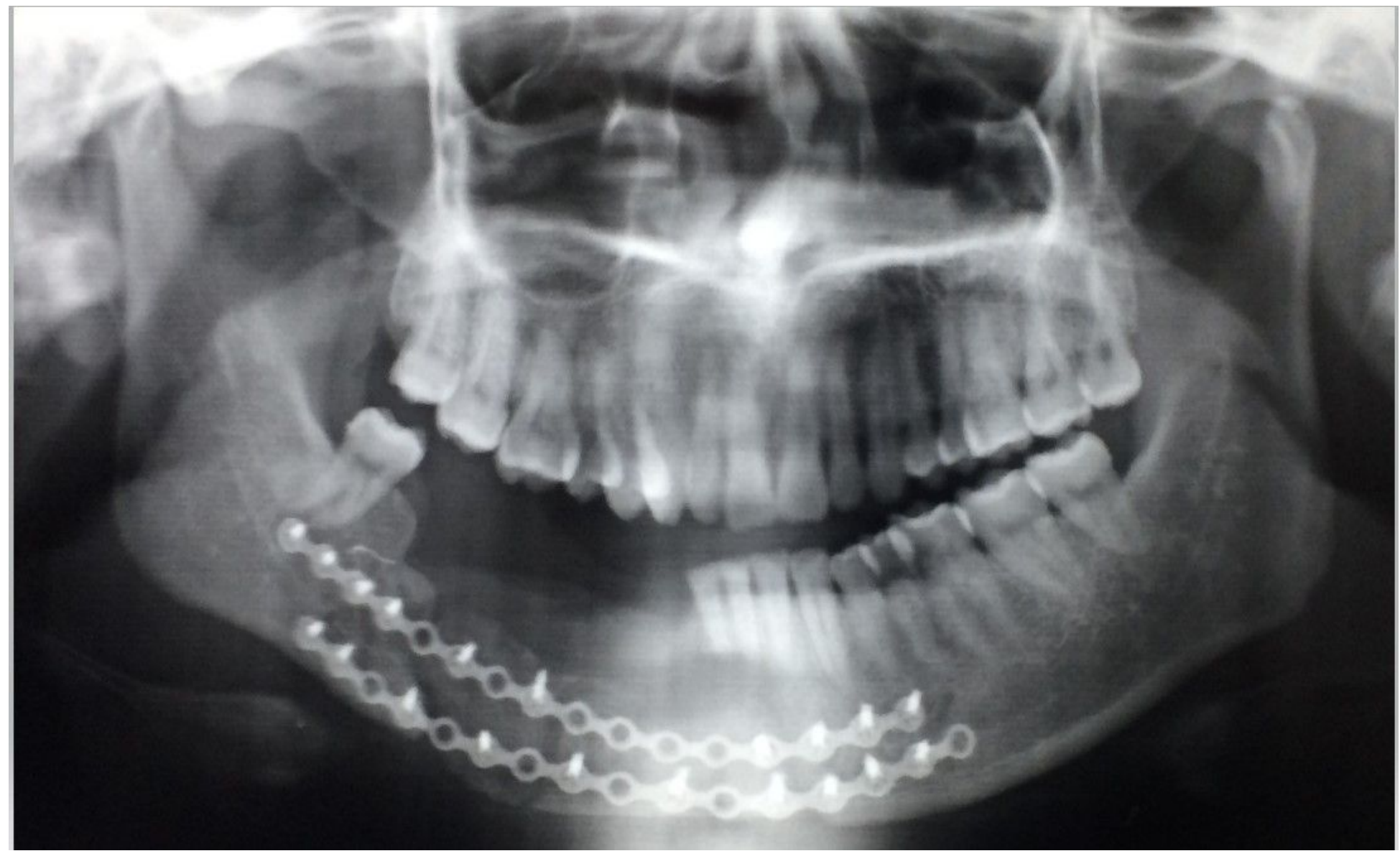

\section{Figure 5}

The follow-up of Panoramic radiographs $₫ 2017 \rrbracket$ : Reconstruction of the mandible using the autogenous iliac bone.

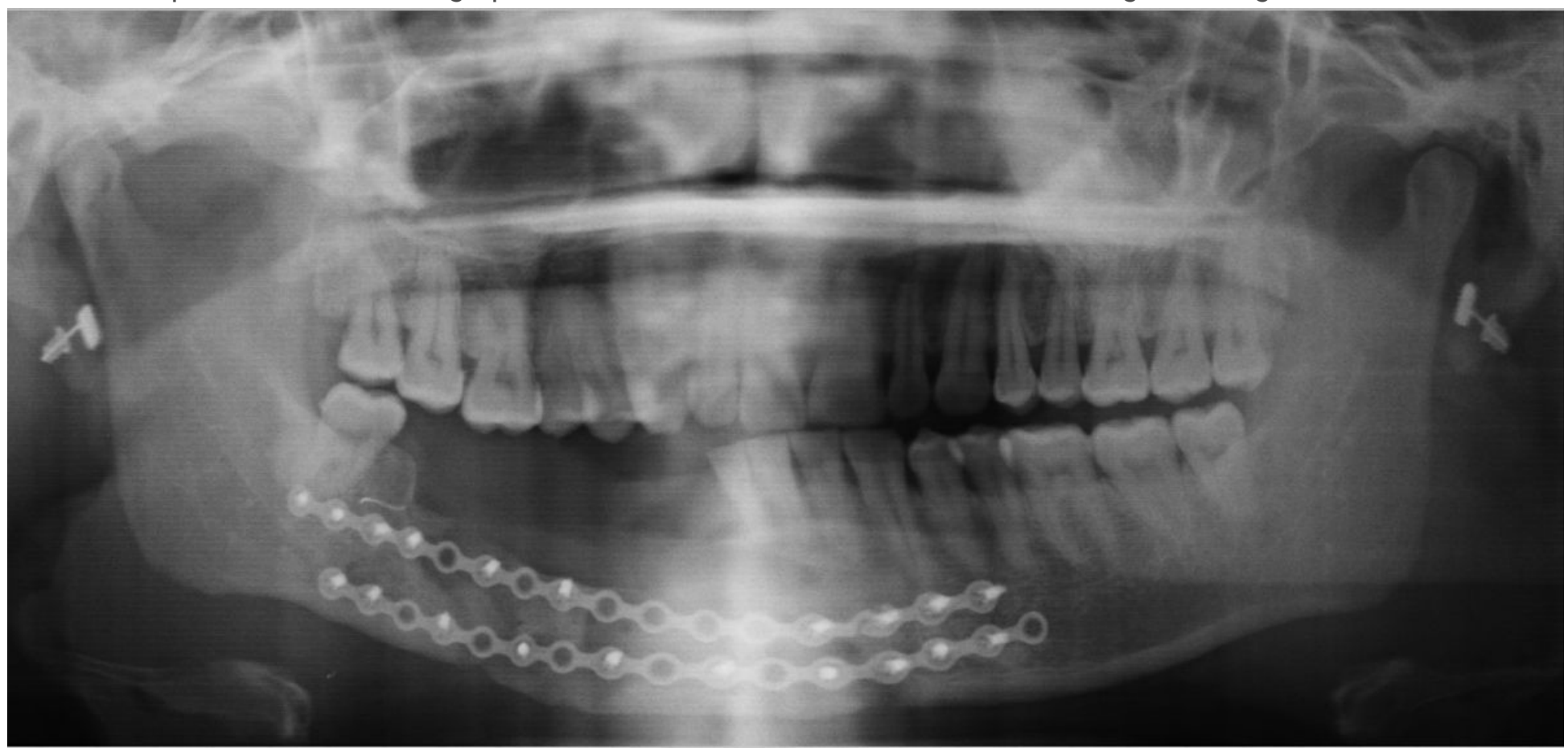

\section{Figure 6}

The follow-up of Panoramic radiographs $₫ 2018 \rrbracket$ : Reconstruction of the mandible using the autogenous iliac bone. 


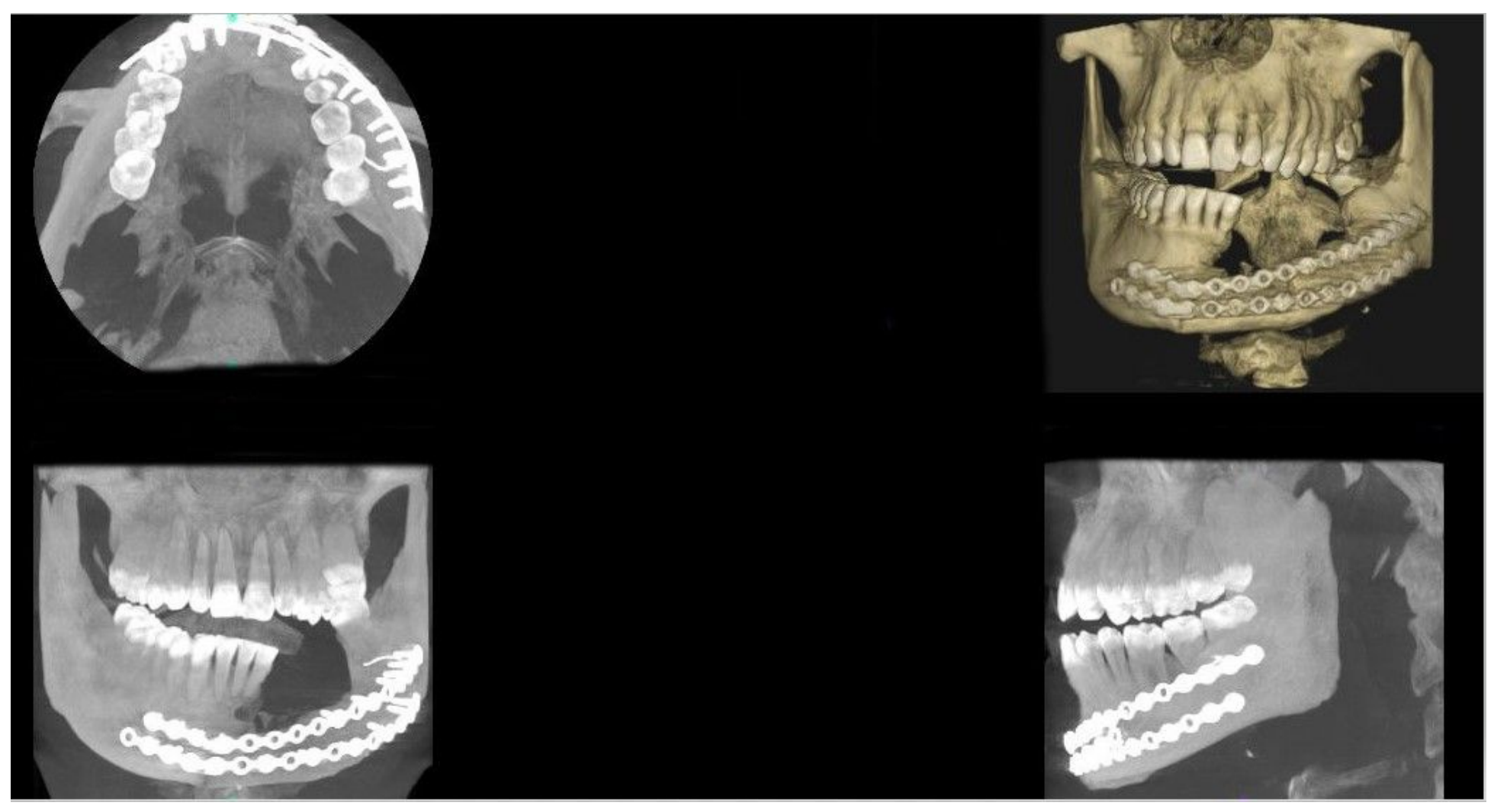

\section{Figure 7}

The follow-up of Cone beam CT $\triangle$ CBCT $\otimes \square 2019 \rrbracket:$ Reconstruction of the mandible using the autogenous iliac bone. 